\title{
KOMPARASI EFISIENSI PENGHIMPUNAN DANA PIHAK KETIGA BANK UMUM SYARIAH DAN BANK UMUM KONVENSIONAL DI INDONESIA DENGAN METODE DATA ENVELOPMENT ANALYSISI)
}

\author{
Yuliati \\ Program Studi S1 Ekonomi Islam-Fakultas Ekonomi dan Bisnis-Universitas Airlangga \\ Email: yuliati-feb 12.web.unair.ac.id \\ Noven Suprayogi \\ Departemen Ekonomi Syariah-Fakultas Ekonomi dan Bisnis-Universitas Airlangga \\ Email: noven2005@gmail.com
}

\begin{abstract}
:
This study aims to determine and comparing the level of third-party funds accumulation efficiency of Islamic Banks and Conventional Banks in Indonesia. This study uses a quantitative non-parametric approach with Data Envelopment Analysis (DEA) CRS and VRS assumption, and statistical tool namely Mann-Whitney U-Test. The samples are 10 Islamic Banks and 13 Conventional Banks those comply with the specified sample criteria. During 2010 to 2014, Islamic Banks has efficiency level of third-party funds accumulation relatively higher than Conventional Banks based on CRS and VRS assumption. Source of inefficiency in Islamic Banks is the scale of third-party funds accumulation. While the hypothesis test showed there was no significant difference in the level of third-party funds accumulation efficiency between Islamic Banks and Conventional Banks in Indonesia with the assumption of CRS, VRS, and Scale efficiency.
\end{abstract}

Keywords: Efficiency, Data Envelopment Analysis (DEA), Third-Party Funds Accumulation

\section{PENDAHULUAN}

Sistem perbankan di Indonesia menerapkan dual banking system, yaitu terselanggaranya dua sistem perbankan (konvensional dan syariah) secara berdampingan. Hal ini diakui dan dikenal sejak diberlakukannya Undang-Undang No.7 tahun 1992 tentang perbankan, yang kemudian diperbarui dengan UndangUndang No.10 tahun 1998. Seiring dengan berjalannya waktu, pemerintah semakin memberikan dukungan adanya bank syariah. Hal ini terbukti dengan disahkannya peraturan yang mengkhususkan tentang perbankan syariah yaitu Undang-Undang No.21 tahun 2008 tentang Perbankan Syariah pada 17 Juni 2008 lalu.

Dalam perkembangannya sampai pada saat ini, industri perbankan syariah di Indonesia semakin meningkat. Hingga tahun 2013, telah tercatat 11 Bank Umum Syariah (BUS), 24 Unit Usaha Syariah (UUS), 160 Bank Pembiayaan Rakyat Syariah (BPRS) dengan jumlah kantor perbankan syariah sebanyak 2.830 yang tersebar di hampir seluruh wilayah Indonesia (SPS, 2014: 1).

Dari segi pendanaan, bank syariah dihadapkan pada tantangan terbatasnya daya saing dalam menempatkan dana pihak hak ketiga yang "murah" dan berjangka waktu relatif panjang (Laporan Perkembangan Keuangan Syariah, 2013). Komposisi DPK pada Bank Umum Syariah

1) Jurnal ini merupakan bagian dari Skripsi yang ditulis oleh Yuliati; 041211432016 , yang diuji pada tanggal 10 Februari 2016 
Yuliati, et al/Jurnal Ekonomi Syariah Teori dan Terapan Vol. 3 No. 4 April 2016: 280-294; KOMPARASI EFISIENSI PENGHIMPUNAN DANA PIHAK KETIGA BANK UMUM SYARIAH DAN BANK UMUM KONVENSIONAL DI INDONESIA DENGAN METODE DATA ENVELOPMENT ANALYSIS

didominasi oleh instrumen deposito yang mencapai lebih dari $50 \%$ dari total DPK. Bahkan pada tahun 2011 dan tahun 2014, instrumen deposito pada Bank Umum Syariah mencapai lebih dari $60 \%$ dari total DPK.

Hal ini berbeda dengan Bank Umum Konvensional dengan komposisi DPK yang relatif stabil dan berimbang. Dalam rentang periode 2011-2014, instrumen deposito tidak pernah mencapai $50 \%$ dari total DPK yang ada, dan hanya berkisar $20 \%$ hingga $24 \%$ dari deposito yang merupakan deposito dengan jangka waktu 1 bulan. Sedangkan pada Bank Umum Syariah $60 \%$ hingga $70 \%$ dari total deposito merupakan deposito dengan jangka waktu 1 bulan.

Berdasarkan fakta tersebut di atas, maka penelitian ini akan difokuskan pada penilaian efisiensi dari segi penghimpunan dana pihak ketiga. Apabila suatu bank mampu efisien baik dari sisi pendanaan maupun, maka akan memberikan keunggulan kompetitif bagi bank tersebut.

Konsep efisiensi memang merupakan salah satu prinsip yang sangat penting dalam bisnis. Dari sudut pandang ekonomi islam, setiap muslim dalam menjalankan bisnisnya haruslah memiliki keinginan yang kuat untuk meningkatkan efisiensi, yaitu dengan mengurangi biaya demi kebaikan konsumennya (Affandi (2002) dalam Kamaruddin,et.al 2008:33) ). Konsep efisiensi ini sejalan dengan prinsip Syariah yang bertujuan untuk mencapai dan menjaga maqashid Syariah yaitu terpeliharanya al-maal (Kamaruddin,et.al 2008:33). Konsep ini sebagaimana terkandung dalam Al-Qur'an Surat AlIsraa' (17) ayat 26-27:

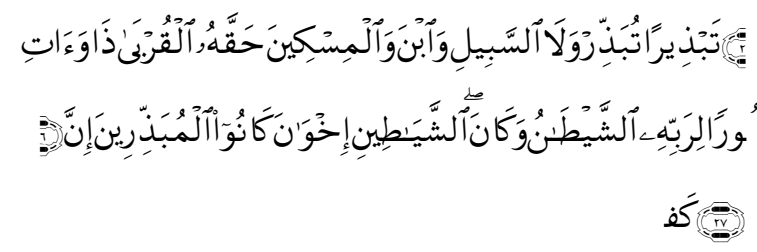

Wa āti żal-qurbā ḥaqqahu wal-miskīna wabnas-sabili wa lā tubażżir tabżīrā. Innalmubażżirinna kānū ikhwānasy-syayāïÊn,wa kÉnasy-syaiïānu lirabbihê kafūrā

Artinya: "dan berikanlah kepada keluarga-keluarga yang dekat akan haknya, kepada orang miskin dan orang yang dalam perjalanan dan janganlah kamu menghambur-hamburkan (hartamu) secara boros. Sesungguhnya pemboros-pemboros itu adalah saudarasaudara syaitan dan syaitan itu adalah sangat ingkar kepada Tuhannya" (Q.S AlIsra'/17:26-27, Departemen Agama Republik Indonesia, 201 1: 284).

Metode pengukuran efisiensi yang digunakan oleh peneliti adalah metode Data Envelopment Analysis (DEA). Metode DEA merupakan suatu teknik pemrograman matematika (mathematical promgramming) untuk mengukur tingkat efisiensi dari Unit Pengambil Keputusan (UPK) atau Decision Making Unit (DMU) relatif terhadap UPK yang sejenis ketika semua unit-unit ini berada pada atau di bawah "kurva" efficiency frontiernya ( Hidayat, 2014).

Terdapat dua model yang sering digunakan dalam pendekatan DEA yakni model Constant Return to Scale (CRS) yang dikembangkan oleh Charnes, 
Yuliati, et al/Jurnal Ekonomi Syariah Teori dan Terapan Vol. 3 No. 4 April 2016: 280-294; KOMPARASI EFISIENSI PENGHIMPUNAN DANA PIHAK KETIGA BANK UMUM SYARIAH DAN BANK UMUM KONVENSIONAL DI INDONESIA DENGAN METODE DATA ENVELOPMENT ANALYSIS

Cooper, dan Rhodes pada tahun 1978, dan model Variable Return to Scale (VRS) yang dikembangkan oleh Banker, Charnes, dan Cooper pada tahun 1984. Hasil perhitungan DEA dengan pendekatan CRS ini disebut juga dengan efisiensi keseluruhan (Overall Efficiency). Hasil perhitungan DEA dengan pendekatan VRS disebut juga dengan efisiensi Teknik (Technical Efficiency). Dari kedua model pendekatan tersebut kemudian diformulasikan perhitungan kinerja efisiensi skala atau Scale Efficiency (SE) (Pratikto dan lis Sugianto, $2011: 110$ ).

Berdasarkan uraian latar belakang di atas, maka peneliti merumuskan masalah penelitian sebagai berikut:

1. Berapakah tingkat efisiensi penghimpunan dana pihak ketiga Bank Umum Syariah dan Bank Umum Konvensional di Indonesia?

2. Apakah terdapat perbedaan efisiensi penghimpunan dana pihak ketiga dengan asumsi CRS pada Bank Umum Syariah dan Bank Umum Konvensional di Indonesia?

3. Apakah terdapat perbedaan efisiensi penghimpunan dana pihak ketiga dengan asumsi VRS pada Bank Umum Syariah dan Bank Umum Konvensional di Indonesia?

4. Apakah terdapat perbedaan efisiensi skala penghimpunan dana pihak ketiga pada Bank Umum Syariah dan Bank Umum Konvensional di Indonesia? Adapun tujuan penelitian ini adalah:
1. Untuk Mengetahui tingkat efisiensi penghimpunan dana pihak ketiga pada Bank Umum Syariah dan Bank Umum Konvensional di Indonesia.

2. Untuk mengetahui perbedaan efisiensi penghimpunan dana pihak ketiga dengan asumsi CRS pada Bank Umum Syariah dan Bank Umum Konvensional di Indonesia.

3. Untuk mengetahui perbedaan efisiensi penghimpunan dana pihak ketiga dengan asumsi VRS pada Bank Umum Syariah dan Bank Umum Konvensional di Indonesia.

4. Untuk mengetahui perbedaan efisiensi skala penghimpunan dana pihak ketiga pada Bank Umum Syariah dan Bank Umum Konvensional di Indonesia.

\section{Landasan Teori}

Ascarya (2006:1 12) menjelaskan: produk-produk pendanaan bank syariah ditujukan untuk mobilisasi dan investasi tabungan untuk pembangunan perekonomian dengan cara yang adil sehingga keuntungan yang adil dapat dijamin bagi semua pihak.Dalam hal ini, bank syariah melakukan penghimpunan dana tidak dengan prinsip bunga (riba), melainkan dengan prinsip-prinsip yang sesuai dengan syariat Islam, terutama wadiah (titipan) dan mudharabah (bagi hasil).

Kegiatan-kegiatan penghimpunan dana yang dapat dilakukan oleh bank umum syariah adalah:

a) Giro berdasarkan prinsip wadiah

b) Tabungan berdasarkan prinsip wadiah dan mudharabah 
Yuliati, et al/Jurnal Ekonomi Syariah Teori dan Terapan Vol. 3 No. 4 April 2016: 280-294; KOMPARASI EFISIENSI PENGHIMPUNAN DANA PIHAK KETIGA BANK UMUM SYARIAH DAN BANK UMUM KONVENSIONAL DI INDONESIA DENGAN METODE DATA ENVELOPMENT ANALYSIS

c) Deposito berjangka berdasarkan prinsip mudharabah

Produk dana pihak ketiga bank konvensional menggunakan tiga macam jenis simpanan (rekening). Masing-masing jenis simpanan memiliki keunggulan tersendiri, sehingga bank harus pandai dalam menyiasati pemilihan sumber dana. Sumber dana yang dimaksud adalah:

a) simpanan giro

b) simpanan tabungan

C) simpanan deposito

Menurut Arthur dan Steven (2003:15), efisiensi dalam konsep ekonomi merujuk pada sejumlah konsep yang terkait pada penggunaan, pemaksimalan serta pemanfaatan seluruh sumber daya dalam proses produksi barang dan jasa. Penggunaan sumber daya bisa dikatakan efisien apabila: (1) seluruh sumber daya yang tersedia sepenuhnya digunakan; (2) corak penggunaannya adalah sudah sedemikian rupa sehingga tidak terdapat lagi corak penggunaan lain yang akan memberikan tambahan kemakmuran bagi masyarakat/individe (Sukirno, Sadono, 2008: 256).

Dari sudut pandang ekonomi islam, konsep efisiensi sejalan dengan prinsip Syariah yang bertujuan untuk mencapai dan menjaga maqashid syariah yaitu terpeliharanya al-maal (Kamaruddin,et.al 2008:33). Konsep efisiensi pada dasarnya adalah menghindari segala bentuk pemborosan sebagaimana terkandung dalam surat Al-Israa' ayat 26-27:

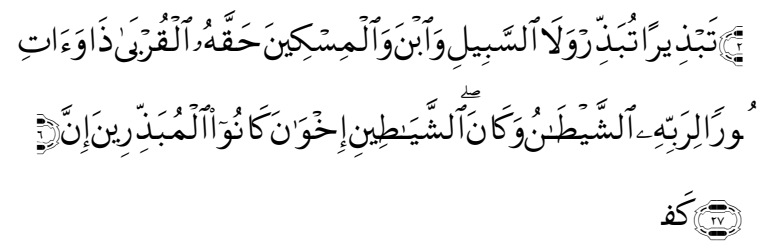

Wa āti żal-qurbā ḥaqqahu wal-miskīna wabnas-sabili wa lā tubażżir tabżīrā. Innalmubażżirina kānū ikhwānasy-syayāïÊn,wa kÉnasy-syaiïānu lirabbihê kafūrā

Artinya: "dan berikanlah kepada keluarga-keluarga yang dekat akan haknya, kepada orang miskin dan orang yang dalam perjalanan dan janganlah kamu menghambur-hamburkan (hartamu) secara boros. Sesungguhnya pemboros-pemboros itu adalah saudarasaudara syaitan dan syaitan itu adalah sangat ingkar kepada Tuhannya"(Q.S AlIsra'/17:26-27, Departemen Agama Republik Indonesia, 2011: 284).

Makna kata 'boros' pada ayat di atas adalah berasal dari kata tabdzir yang merupakan kata kerja (fi'il) dari kata sifat (isim) mubadzir yang oleh Imam Syafi'idiartikan sebagai membelanjakan harta tidak pada jalannya. Lebih lanjut dijelaskan oleh Mujahid bahwa walaupun seluruh harta dihabiskan untuk jalan yang benar, maka tidak dikategorikan sebagai mubadzir. Sebaliknya, walaupun hanya segantang padi tapi digunakan untuk hal yang tidak benar maka hal itu disebut dengan mubadzir (Hamka, 2007: 48).

Berdasarkan konsep tersebut di atas, maka konsep efisiensi operasional penghimpunan dana pihak ketiga pada perbankan syariah merujuk pada keharusan manajemen bank untuk bisa mengelola pengeluaran untuk pos-pos penggerak biaya dengan cara yang tepat guna dan benar, hemat, layak, dan 
Yuliati, et al/Jurnal Ekonomi Syariah Teori dan Terapan Vol. 3 No. 4 April 2016: 280-294; KOMPARASI EFISIENSI PENGHIMPUNAN DANA PIHAK KETIGA BANK UMUM SYARIAH DAN BANK UMUM KONVENSIONAL DI INDONESIA DENGAN METODE DATA ENVELOPMENT ANALYSIS

wajar. Hal ini sebagaimana terkandung dalam hadits yang diriwayatkan oleh Ishaq bin Ibrahim Al Handlali telah dikabarkan kepadanya dari Jarir dari Manshur dari Asy Sya'bi dari Warrad bekas budak Al Mughirah bin Syu'bah, dari Mughirah binSyu'bah dari Rasulullah shallallahu 'alaihi wasallam, sesungguhnya Rasulullah shallallahu 'alaihi wasallam bersabda:

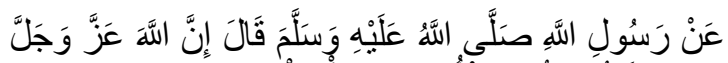

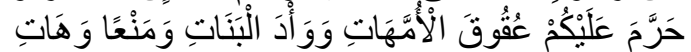

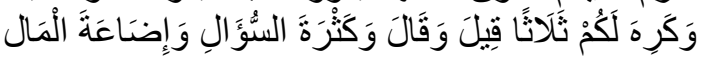

'an rasūlullahu 'alayhi wa sallama qāla innallāha 'azza wa jalla harrama 'alaykum 'vqūqa al'ammahāti wa wa'adalbanāti wa man'awwahāti wa kariha lakum śalās̄ā waqāla wa kaśratassawli wa iḍhā'atalmāl

Artinya:"Rasulullah shallallahu 'alaihi wasallam bersabda sesungguhnya Allah 'azza wajalla mengharamkan kalian mendurhakai seorang ibu, mengubur anak perempuan hidup-hidup, dan tidak suka memberi dan suka meminta-minta. Dan membenci atasmu tiga perkara; mengatakan sesuatu yang tidak jelas sumbernya, banyak bertanya dan menyia-nyiakan harta."(HR. Muslim No.3237)

Dimana pada hadits di atas, makna idho'atul maal adalah menggunakannya untuk selain ketaatan kepada Allah atau membelanjakannya secara boros.

Pengukuran efisiensi kegiatan penghimpunan dana pihak ketiga pada bank syariah dan bank konvensional didasarkan pada faktor-faktor operasional bank. Sebagai bagian dari kegiatan operasional bank sebagaimana dijelaskan oleh Bastian, Indra dan Suhardjono dalam buku Akuntansi Perbankan (2006:287), efisiensi dalam penghimpunan dana dapat diukur dengan menggunakan instrumen biaya dana (cost of fund), yang terdiri dari biaya bunga dan biaya promosi, serta biaya overhead. Penggunaan konsep teori tersebut pada perbankan syariah tentu saja bisa dilakukan dengan melakukan penyesuaian dalam beberapa faktor, yaitu diantaranya penghapusan konsep bunga dalam instrumen biaya dana.

Penulis tidak memperhitungkan biaya overhead dalam pengukuran efisiensi penghimpunan dana pihak ketiga ini dikarenakan biaya tersebut digunakan untuk kegiatan operasional keseluruhan bank. Alokasi biaya overhead pada masing-masing kegiatan bank sangat sulit dilakukan, karena tidak ada proses alokasi biaya secara jelas. Untuk menghindari terjadinya bias dalam hasil penelitian, maka penulis hanya mempertimbangkan biaya dana dan biaya promosi sebagai input dalam pengukuran efisien penghimpunan dana pihak ketiga.

Data Envelopment Analysis (DEA) pertama kali diperkenalkan oleh Charnes, Cooper, dan Rhodes (1978) sebagai metode untuk mengukur efisiensi relatif suatu unit organisasi yang menggunakan multiple input untuk menghasilkan multiple output.Skor efisiensi yang dihasilkan Data Envelopment Analysis (DEA) berkisar 0-1 atau $100 \%$. Jika sebuah DMU memiliki nilai kurang dari 1 maka dianggap sebagai 
Yuliati, et al/Jurnal Ekonomi Syariah Teori dan Terapan Vol. 3 No. 4 April 2016: 280-294; KOMPARASI EFISIENSI PENGHIMPUNAN DANA PIHAK KETIGA BANK UMUM SYARIAH DAN BANK UMUM KONVENSIONAL DI INDONESIA DENGAN METODE DATA ENVELOPMENT ANALYSIS

unit yang relatif tidak efisien dibandingkan unit-unit lainnya.

Terdapat dua model yang umum digunakan dalam mengukur efisiensi relatif, yaitu model CCR dengan asumsi CRS (Constan Return to Scale) dan BCC dengan asumsi VRS (Variable Return to Scale) (Hadad et al, 2003: 13):

\section{CCR Model}

Model ini diperkenalkan oleh Charnes, Cooper, dan Rhodes (1978). Asumsi yang digunakan pada model ini adalah Constant Return to Scale (CRS) yang artinya suatu DMU telah berada pada kondisi optimalnya. Sehingga perubahan proporsional pada tingkat input akan menghasilkan perubahan proporsional yang sama pada tingkat output. Jadi bila dilakukan penambahan $1 \%$ input akan menghasilkan penambahan $1 \%$ output. Pengukuran efisiensi dengan model CCR merupakan pengukuran overall technical efficiency (OTE) yang merupakan hasil pengalian antara efisiensi teknis dan efisiensi skala (TE $x$ SE) (Moussawi dan Obeid,2011 dalam Sari,2015:41).

2. BCC Model

Model ini diperkenalkan oleh Banker, Charnes, dan Cooper (1984). Asumsi yang digunakan dalam model ini adalah Variable Return to Scale (VRS) yang artinya DMU belum berada pada tingkat optimalnya. Sehingga rasio pada setiap penambahan input dan output tidak sama. sehingga setiap penambahan input sebesar $x$ tidak akan menyebabkan peningkatan pada output sebesar $x$, melainkan bisa lebih kecil atau lebih besar (Moussawi dan Obeid,2011 dalam Sari,2015:41).

Farrel (1957) dalam Wahab,et al (2014:182-183) menguraikan bahwa pengukuran efisiensi dengan metode DEA ada dua orientasi yang digunakan:

1. Input Orientation (Orientasi input)

2. Output Orientation (Orientasi output)

Berdasarkan latar belakang, rumusan masalah, tujuan penelitian, landasan teori yang telah dikemukakan maka hipotesis dalam penelitian ini adalah:

$\mathrm{H}_{1}$ : Terdapat perbedaan yang signifikan efisiensi penghimpunan dana pihak ketiga yang signifikan dengan asumsi CRS pada Bank Umum Syariah (BUS) dan Bank Umum Konvensional (BUK) di Indonesia.

$\mathrm{H}_{2}$ : Terdapat perbedaan yang signifikan efisiensi penghimpunan dana pihak ketiga yang signifikan dengan asumsi VRS pada Bank Umum Syariah (BUS) dan Bank Umum Konvensional (BUK) di Indonesia.

$\mathrm{H}_{3}$ : Terdapat perbedaan yang signifikan efisiensi skala penghimpunan dana pihak ketiga yang signifikan pada Bank Umum Syariah (BUS) dan Bank Umum Konvensional (BUK) di Indonesia.

\section{METODE PENELITIAN}

Pendekatan Penelitian 
Yuliati, et al/Jurnal Ekonomi Syariah Teori dan Terapan Vol. 3 No. 4 April 2016: 280-294; KOMPARASI EFISIENSI PENGHIMPUNAN DANA PIHAK KETIGA BANK UMUM SYARIAH DAN BANK UMUM KONVENSIONAL DI INDONESIA DENGAN METODE DATA ENVELOPMENT ANALYSIS

Pendekatan yang digunakan dalam penelitian ini adalah penelitian kuantitatif. Alat analisis kuantitatif yang digunakan dalam penlitian ini adalah Data Envelopment Analysis (DEA).

\section{Variabel Input}

1. Biaya Dana

Biaya yang telah dikeluarkan sebagai kompensasi telah menarik dana dari masyarakat yaitu berupa biaya bunga pada Bank Umum Konvensional dan hak pihak ketiga atas bagi hasil dan biaya bonus pada Bank Umum Syariah.

Nominal biaya bunga dan hak pihak ketiga atas bagi hasil digunakan adalah khusus yang diberikan kepada pihak ketiga, yang didapatkan dari laporan laba rugi dan catatan atas laporan kevangan. Satuan yang digunakan dalam variabel ini adalah jutaan rupiah.

2. Biaya Promosi

Total biaya promosi yang dikeluarkan oleh Bank Umum Syariah dan Bank Umum Konvensional pada setiap periode. Biaya promosi dapat dilihat pada laporan laba/rugi masing-masing bank konvensional dan bank syariah. Satuan yang digunakan dalam variabel ini adalah jutaan rupiah.

\section{Variabel Output}

1. Dana Pihak Ketiga

Jumlah dana pihak ketiga dalam penelitian ini dapat dilihat pada sisi pasiva laporan posisi keuangan berupa giro, tabungan, dan deposito pada bank konvensional. Sedangkan pada bank syariah terdiri dari giro wadiah, tabungan wadiah, tabungan mudharabah, serta deposito mudharabah. Satuan yang digunakan dalam variabel ini adalah jutaan rupiah.

\section{Populasi dan Sampel}

Populasi dalam penelitian ini adalah seluruh Bank Umum Syariah (BUS) dan Bank Umum Konvensional (BUK) yang ada di Indonesia. Pengambilan sampel dalampenelitian ini dilakukan dengan purposive sampling.

\section{Jenis dan Sumber Data}

Data yang digunakan dalam penelitian ini adalah data sekunder. Sedangkan pengumpulan data dalam penelitian ini dilakukan dengan metode kepustakaan atau library research.

\section{Teknik Analisis Data}

Perhitungan nilai efisiensi ini didasarkan pada data-data dari variabel input dan output sebagaimana ditentukan sebelumnya dengan dirumuskan sebagai berikut: (Moussawi dan Obeid,2011 dalam Sari, 2015). $\max h_{k}=$

$\frac{\sum_{r=1}^{s} u_{r} y_{r j}}{\sum_{i=1}^{m} v_{i} x_{i j}}$.

Dimana:

$h_{k}=$ Nilai efisiensi penghimpunan dana pihak ketiga

$u_{r} y_{r j}=$ Output terbobot (Total Dana Pihak Ketiga) 
Yuliati, et al/Jurnal Ekonomi Syariah Teori dan Terapan Vol. 3 No. 4 April 2016: 280-294; KOMPARASI EFISIENSI PENGHIMPUNAN DANA PIHAK KETIGA BANK UMUM SYARIAH DAN BANK UMUM KONVENSIONAL DI INDONESIA DENGAN METODE DATA ENVELOPMENT ANALYSIS

$v_{i} x_{i j}=$ Input terbobot (Biaya dana dan Biaya Promosi)

Hasil pengukuran efisinsi penghimpunan dana pihak ketiga dengan model CRS dan VRS akan menghasilkan nilai efisiensi teknis dan efisiensi skala yang dirumuskan sebagai berikut:

$S E=O E / T E$

Dimana:

SE: Scale Efficiency

OE: Overall Efficiency (Model CRS)

TE: Technical Efficiency (Model VRS)

Pengukuran efisiensi pada penelitian ini akan menggunakan bantuan perangkat aplikasi MaxDEA. DMU yang memiliki nilai efisiensi 1 (satu) merupakan DMU yang efisien, sedangkan DMU dengan nilai efisiensi kurang dari 1 (satu) adalah DMU yang tidak efisien. Nilai efisien ini merupakan nilai efisiensi relatif antar DMU dengan DMU yang paling efisien menjadi benchmark acuan bagi DMU yang lainnya.

2. Uji Hipotesis

Model yang digunakan untuk menguji hipotesis adalah uji beda Mann-Whitney U-Test. Penggunaan model statistik Mann-Whitney U-Test. Jumlah data kelompok sampel I dan kelompok sampel II tidak harus sama; iv. Data berskala ordinal, interval, atau rasio.Perhitungan nilai uji statistik model Mann-Whitney U-Test adalah :

$$
\begin{aligned}
& U_{1_{\text {hitung }}}= \\
& n_{1} n_{2} \frac{n_{1}\left(n_{1}+1\right)}{2}-R_{1}
\end{aligned}
$$

Atau

$U_{2_{\text {hitung }}}=$

$n_{1} n_{2} \frac{n_{2}\left(n_{2}+1\right)}{2} R_{2}$

Dengan ketentuan bahwa nilai $U_{\text {hitung }}$ yang diambil adalah nilai $U_{\text {hitung }}$ yang terkecil. Dan untuk memeriksa ketelitian perhitungan digunakan rumus:

$U_{\text {terkecil }}=n_{1} n_{2}-U_{\text {terkecil }}$

Dimana:

$U_{1}$ : Statistik uji $U_{1}$

$U_{2}$ : Statistik uji $U_{2}$

$n_{1}$ : jumlah sampel grup sampel yang lebih besar

$n_{2}$ : jumlah sampel grup sampel yang lebih kecil

$R_{1}$ : Jumlah rank sampel grup sampel yang lebih besar

$R_{2}$ : Jumlah rank sampel grup sampel yang lebih kecil

Dalam penelitian ini perhitungan model statistik Mann-Whitney U-Test akan dilakukan dengan menggunakan program aplikasi SPSS 20.

\section{Hasil dan Pembahasan}

Analisis Komparasi Nilai Efisiensi Model CRS

Berdasarkan tabel 1 dapat disimpulkan bahwa secara umum Bank Umum Syariah relatif lebih efisien dengan asumsi Constant Return to Scale (CRS). Sebagaimana terlihat pada tabel 1 bahwa meskipun tidak berbeda jauh namun terlihat bahwa rata-rata efisiensi 
Yuliati, et al/Jurnal Ekonomi Syariah Teori dan Terapan Vol. 3 No. 4 April 2016: 280-294; KOMPARASI EFISIENSI PENGHIMPUNAN DANA PIHAK KETIGA BANK UMUM SYARIAH DAN BANK UMUM KONVENSIONAL DI INDONESIA DENGAN METODE DATA ENVELOPMENT ANALYSIS

dengan asumsi CRS pada Bank Umum Syariah lebih tinggi dibandingkan dengan rata-rata efisiensi pada Bank Umum Konvensional.

Tabel 1.

\section{Perbandingan Nilai Overall Technical Efficiency (CRS) pada BUS dan BUK}

\begin{tabular}{|l|l|r|}
\hline Kelompok Bank & & CRS \\
\hline BUK & Mean & 0,562 \\
\hline & Min & 0,049 \\
\hline & Max & 1 \\
\hline & SD & 0,28 \\
\hline BUS & Mean & 0,58 \\
\hline & Min & 0,06 \\
\hline & Max & 1 \\
\hline & SD & 0,321 \\
\hline
\end{tabular}

Sumber: Lampiran 2 diolah

Analisis Komparasi Nilai Efisiensi Model CRS

Tabel 2.

Perbandingan Nilai Pure Technical Efficiency (VRS) pada BUS dan BUK

\begin{tabular}{|l|l|r|}
\hline Kelompok Bank & & \multicolumn{1}{|c|}{ VRS } \\
\hline BUK & Mean & 0,687 \\
\hline & Min & 0,115 \\
\hline & Max & 1 \\
\hline & SD & 0,265 \\
\hline BUS & Mean & 0,75 \\
\hline & Min & 0,13 \\
\hline & Max & 1 \\
\hline & SD & 0,267 \\
\hline
\end{tabular}

Sumber: Lampiran 2 diolah

Berdasarkantabel2,secaraumumdapatdisi mpulkanbahwabahwasecaraumumBankU mumSyariahrelatiflebihefisiendalammeng elolafaktorinputuntukmenghasilkanouputy angoptimal.Sebagaimanaterlihatpadatab el2,bahwarata-

ratanilaiefisiensipenghimpunan dana pihak ketiga
denganasumsiVRS(PureTechnicalEfficienc y)padaBankUmumSyariahlebihtinggidiban dingkandenganrata-

ratanilaiefisiensipadaBankUmumKonvensio nal.

\section{Analisis Komparasi Nilai Efisiensi Skala}

Tabel 3.

Perbandingan Nilai Scale Efficiency pada BUS dan BUK

\begin{tabular}{|l|l|r|}
\hline Kelompok Bank & & \multicolumn{1}{|c|}{ SE } \\
\hline BUK & Mean & 0,827 \\
\hline & Min & 0,114 \\
\hline & Max & 1 \\
\hline & SD & 0,252 \\
\hline BUS & Mean & 0,753 \\
\hline & Min & 0,134 \\
\hline & Max & 1 \\
\hline & SD & 0,29 \\
\hline
\end{tabular}

Sumber: Lampiran 2 diolah

Berdasarkan tabel 3 secara umum dapat disimpulkan bahwa Bank Umum Konvensional memiliki rata-rata nilai efisiensi skala (scale efficiency) yang lebih baik bila dengan Bank Umum Syariah.

Secara umum dapat disimpulkan bahwa sumber ketidakefisienan penghimpunan dana pihak ketiga pada Bank Umum Syariah lebih dikarenakan ketidakefisienan dalam skala atau size penghimpunan dana pihak ketiga. Hal ini ditunjukkan dengan tingkat scale Efficiency pada BUS yang lebih rendah bila dibandingkan dengan bank Umum Konvensional, namun pada saat yang sama BUS memiliki tingkat Overall Technical Efficiency(CRS) dan Pure Technical Efficiency (VRS) yang lebih 
Yuliati, et al/Jurnal Ekonomi Syariah Teori dan Terapan Vol. 3 No. 4 April 2016: 280-294; KOMPARASI EFISIENSI PENGHIMPUNAN DANA PIHAK KETIGA BANK UMUM SYARIAH DAN BANK UMUM KONVENSIONAL DI INDONESIA DENGAN METODE DATA ENVELOPMENT ANALYSIS

tinggi bila dibandingkan dengan Bank Umum Konvensional.

Uji Normalitas

Tabel 4.

Hasil Uji Normalitas

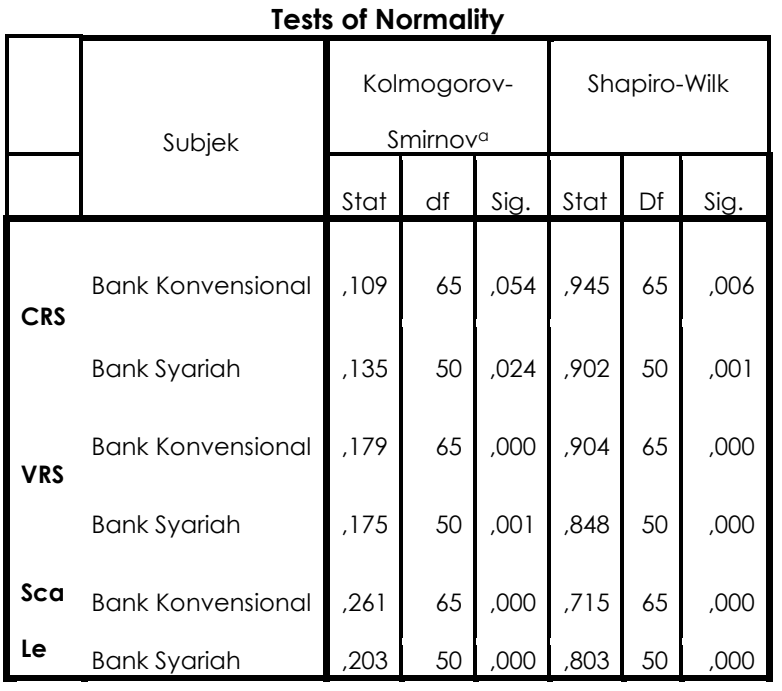

a. Lilliefors Significance Correction Sumber: Lampiran 3

Berdasarkan hasil uji normalitas pada tabel 4, dapat disimpulkan bahwa kelompok sampel Bank Syariah maupun Bank Konvensional tidak terdistribusi secara normal karena memilki nilai signifikansi kurang dari nilai $a=0,05$. Hanya kelompok data nilai efisiensi CRS dari kelompok sampel Bank Konvensional saja yang terdistribusi secara normal karena memiliki nilai signifikansi lebih dari nilai $a=0,05$. Oleh karena itu, model analisis yang digunakan adalah model nonparametrikin dependent sampel MannWhitney U-Test.

\section{Uji Homogenitas}

Pada Tabel5 terlihat bahwa untuk kelompok data nilai efisiensi model VRS dan Skala memiliki signifikansi lebih dari $a=0,05$ yang artinya data bersifat homogen yang artinya memiliki varians yang sama, sehingga asumsi homogenitas terpenuhi dan uji hipotesis dengan model statistik Mann-Whitney Utest dapat dilanjutkan. Tetapi untuk kelompok data nilai efisiensi model CRS berdasarkan pada tabel 5 dapat disimpulkan bahwa data tidak homogen karena memiliki signifikansi kurang dari $a=0,05$ yang artinya memiliki varians yang tidak sama sehingga asumsi homogenitas tidak terpenuhi. Oleh karena itu uji statistik Mann-Whitney U-Test tidak dapat dilakukan. Sebagai alternatif maka akan dilakukan uji statistik two independent sample Kolmogorov Smirnov Z-Test yang lebih sensitif pada mean dan varians.

Tabel 5. Hasil Uji Homogenitas

Test of Homogeneity of Variances

\begin{tabular}{|l|r|r|r|r|}
\hline & \multicolumn{1}{|c|}{$\begin{array}{l}\text { Levene } \\
\text { Statistic }\end{array}$} & \multicolumn{1}{c|}{ df1 } & \multicolumn{1}{c|}{ df2 } & \multicolumn{2}{|c|}{ Sig. } \\
\hline CRS & 4,275 & 1 & 113 &, 041 \\
VRS &, 168 & 1 & 113 &, 683 \\
Scale & 2,635 & 1 & 113 &, 107 \\
\hline
\end{tabular}

Sumber: Lampiran 3

\section{Uji Beda Mann-Whitney U-Test}

Berdasarkan pada tabel 6 dapat diketahui bahwa untuk nilai efisiensi asumsi CRS (Overall Technical Efficiency) memiliki nilai $U$ sebesar 1565,00 dengan nilai signifikansi 0,735 atau lebih dari nilai $\mathrm{a}=0,05$ yang berarti $\mathrm{H}_{0}$ diterima dan $\mathrm{H}_{1}$ ditolak. Sehingga dapat disimpulkan 
Yuliati, et al/Jurnal Ekonomi Syariah Teori dan Terapan Vol. 3 No. 4 April 2016: 280-294; KOMPARASI EFISIENSI PENGHIMPUNAN DANA PIHAK KETIGA BANK UMUM SYARIAH DAN BANK UMUM KONVENSIONAL DI INDONESIA DENGAN METODE DATA ENVELOPMENT ANALYSIS

bahwa tidak terdapat perbedaan yang signifikan nilai efisiensi penghimpunan dana pihak ketiga dengan asumsi CRS pada BUS dan BUK. Untuk nilai efisiensi asumsi VRS (Pure Technical Efficiency) memiliki nilai U sebesar 1395,5 dengan nilai signifikansi 0,188 atau lebih dari nilai $\mathrm{a}=0,05$ yang berarti $\mathrm{H}_{0}$ diterima dan $\mathrm{H}_{1}$ ditolak. Sehingga dapat disimpulkan bahwa tidak terdapat perbedaan yang signifikan nilai efisiensi penghimpunan dana pihak ketiga dengan asumsi VRS pada BUS dan BUK. Kondisi yang sama terjadi pada nilai scale efficiency yang memiliki nilai $U$ sebesar 1392,00 dengan nilai signifikansi 0,188 atau lebih dari $\mathrm{a}=0,05$ yang berarti $\mathrm{H}_{0}$ diterima dan $\mathrm{H}_{1}$ ditolak. Sehingga dapat disimpulkan bahwa tidak terdapat perbedaan yang signifikan nilai efisiensi skala (scale efficiency) penghimpunan dana pihak ketiga pada BUS dan BUK.

Tabel 6.

Hasil Mann-Whitney U-Test

\begin{tabular}{|l|r|c|r|}
\hline \multicolumn{1}{|c|}{ Test Statistics $^{\mathrm{a}}$} \\
\hline CRS & \multicolumn{1}{c|}{ VRS } & \multicolumn{1}{c|}{ Scale } \\
\hline Mann-Whitney U & 1565,000 & 1395,500 & 1392,000 \\
Wilcoxon W & 3710,000 & 3540,500 & 2667,000 \\
Z &,- 339 & $-1,315$ & $-1,316$ \\
Asymp. Sig. (2-tailed) &, 735 &, 188 &, 188 \\
\hline
\end{tabular}

a. Grouping Variable: Subjek

Sumber:Lampiran 4

Tetapi karena asumsi homogenitas yang pada uji asumsi sebelumnya untuk kelompok data CRS tidak terpenuhi maka, pada hasil uji Mann-Whitney U-test ini tidak diketahui apakah perbedaan ini terjadi karena perbedaan antara kedua kelompok atau karena perbedaan yang terjadi di dalam kelompok data. Oleh karena itu, untuk kelompok data nilai efisiensi CRS (Overall Technical Efficiency) akan dilakukan pengujian kembali dengan model uji statistik independent sample Kolmogorov Smirnov Z-Test.

\section{Uji Beda Kolmogorov-Smirnov Z-Test}

Berdasarkan tabel 4.25 dapat dilihat bahwa nilai signifikansinya adalah 0,125. Hasil ini kurang dari nilai $a=0,05$, sehingga $\mathrm{H}_{0}$ diterima yang artinya tidak terdapat perbedaan nilai efisiensi CRS /Overall Technical Efficiency) yang signifikan antara Bank Umum Syariah dan Bank Umum Konvensional.

Tabel 7.

Hasil Uji Kolmogorov-Smirnov Z-Test

Test Statistics ${ }^{a}$

\begin{tabular}{|ll|r|}
\hline & & \multicolumn{1}{|c|}{ CRS } \\
\hline & Absolute &, 222 \\
Most Extreme Differences & Positive &, 222 \\
& Negative &,- 131 \\
Kolmogorov-Smirnov Z & & 1,178 \\
Asymp. Sig. (2-tailed) & &, 125 \\
\hline
\end{tabular}

a. Grouping Variable: Subjek

Sumber:Lampiran 4

\section{Pembahasan Hipotesis}

Tingkat efisiensi dengan asumsi CRS menghasilkan nilai Overall Technical Eficiency (OTE) yaitu nilai efisiensi keseluruhan, dimana nilai tersebut merupakan bauran dari tingkat efisiensi asumsi VRS yang ditunjukkan dengan hasil Pure Technical Efficiency (PTE) dan scale efficiency (efisiensi skala) yang merupakan hasil perbedaan atau gap 
Yuliati, et al/Jurnal Ekonomi Syariah Teori dan Terapan Vol. 3 No. 4 April 2016: 280-294; KOMPARASI EFISIENSI PENGHIMPUNAN DANA PIHAK KETIGA BANK UMUM SYARIAH DAN BANK UMUM KONVENSIONAL DI INDONESIA DENGAN METODE DATA ENVELOPMENT ANALYSIS

pada nilai OTE dan PTE (Kumar dan Rachita Gulati, 2008: 42). Nilai Efisiensi PTE bertujuan untuk mengukur tingkat efisiensi teknis manajerial sedangkan efisiensi skala bertujuan untuk mengukur efisiensi dari skala produksi.

Hasil pengujian hipotesis
menunjukkan bahwa dari ketiga nilai efisiensi penghimpunan dana pihak ketiga Bank Umum Syariah dan Bank Umum Konvensional yaitu asumsi CRS (Constant Return to Scale), VRS (Variable Return to Scale), dan Scale Efficiency tidak berbeda signifikan.

Berdasarkan hasil uji hipotesis disimpulkan bahwa nilai efisiensi Bank Umum Syariah dan Bank Umum Konvensional tidak berbeda signifikan dengan asumi CRS. Hal ini menunjukkan bahwa bank umum syariah dan bank umum konvensional pada tingkat ukuran (size) yang setara, secara umum tidak memiliki perbedaan yang signifikan dalam efisiensi penghimpunan dana pihak ketiga dari segi efisiensi manajemen operasional maupun dari efisiensi skala. Karena pada asumsi CRS ini merupakan nilai efisiensi secara keseluruhan maka perlu diketahui apakah nilai efisiensi bank syariah tersebut dikarenakan dari segi manajerial ataukah dari segi skala.

Dari segi VRS, hasil uji hipotesis menunjukkan bahwa efisiensi bank umum syariah dan bank umum konvensional tidak berbeda signifikan. Mengacu pada konsep efisiensi dengan asumsi VRS yang dijelaskan oleh Moussawi dan Obeid
(2011) dalam Sari (2015:41) bahwa setiap penambahan input sebesar $x$ tidak akan menyebabkan peningkatan pada output sebesar x pula, melainkan bisa lebih kecil atau lebih besar. Sehingga apabila bank umum syariah memiliki tingkat efisiensi PTE yang tidak berbeda signifikan dengan bank umum konvensional berarti peningkatan variabel-variabel input berupa biaya dana dan biaya promosi sebesar 1 unit dapat menghasilkan variabel output berupa dana pihak ketiga yang peningkatannya sama antara bank umum syariah dan umum konvensional. Hal ini dapat dilihat pada tabel 4.26, yang menunjukkan bahwa selama tahun 2011 hingga tahun 2014, bank umum syariah dan bank umum konvensional memiliki rata-rata pertumbuhan variabel input dan variabel output yang hampir sama, atau tidak berbeda signifikan. Sehingga kondisi tersebut mengakibatkan hasil tingkat efisiensi dengan asumsi VRS bank umum syariah dan bank umum konvensional tidak berbeda signifikan.

Tabel 8.

Rata-Rata Pertumbuhan Variabel Input dan Variabel Output Bank Umum Syariah dan Bank Umum Konvensional Tahun 2011 - 2014

\begin{tabular}{|c|c|c|c|c|c|c|}
\hline & & \multicolumn{4}{|c|}{ Tahun } & \multirow{2}{*}{$\begin{array}{l}\text { Rata2 } \\
\text { Pertum } \\
\text { buhan }\end{array}$} \\
\hline & & 2011 & 2012 & 2013 & 2014 & \\
\hline \multirow{2}{*}{$\begin{array}{l}\text { Variabel } \\
\text { Input }\end{array}$} & BUS & 22,42 & 16,30 & 30,51 & 35,01 & 26,06 \\
\hline & BUK & 43,99 & 24,50 & 16,15 & 32,23 & 29,22 \\
\hline \multirow{2}{*}{$\begin{array}{l}\text { Variabel } \\
\text { Output }\end{array}$} & BUS & 53,39 & 19,37 & 21,52 & 16,55 & 27,71 \\
\hline & BUK & 39,10 & 32,11 & 5,71 & 21,71 & 24,66 \\
\hline
\end{tabular}

Sumber: Lampiran 1, data diolah

Uji hipotesis dari segi scale efficiency (efisiensi skala) juga 
Yuliati, et al/Jurnal Ekonomi Syariah Teori dan Terapan Vol. 3 No. 4 April 2016: 280-294; KOMPARASI EFISIENSI PENGHIMPUNAN DANA PIHAK KETIGA BANK UMUM SYARIAH DAN BANK UMUM KONVENSIONAL DI INDONESIA DENGAN METODE DATA ENVELOPMENT ANALYSIS

menunjukkan hasil bahwa bank umum syariah dan bank umum konvensional tidak berbeda signifikan. Hal ini dapat diakibatkan karena sampel yang digunakan dalam penelitian ini adalah bank umum konvensional yang memiliki ukuran (size) setara dengan bank umum syariah, yang dilihat berdasarkan total asetnya. Sehingga, pada ukuran (size) yang setara, bank umum syariah tidak berbeda signifikan dengan bank umum konvensional.

Uraian di atas menunjukkan bahwa baik dari segi efisensi skala (scale efficiency) maupun dari segi efisiensi teknis manajemen (pure technical efficiency) bank umum syariah dan bank umum konvensional tidak berbeda signifikan. Sehingga dapat disimpulkan bahwa pada ukuran (size) yang setara, bank umum syariah dan bank umum konvensional tidak berbeda signifikan pada tingkat efisiensi secara keseluruhan (overall technical efficiency)

Apabila dilihat dari perspektif kevangan Islam, konsep efisiensi ini sejalan dengan prinsip Syariah yang bertujuan untuk mencapai dan menjaga maqashid Syariah yaitu terpeliharanya al-maal (Affandi, 2002 dalam Kamaruddin,et.al 2008:33). Dalam memelihara al-maal (harta) tersebut didasarkan pada ketentuan syariah yaitu menghindari segala bentuk pemborosan sebagaimana terkandung dalam surat Al-Israa' ayat 2627:

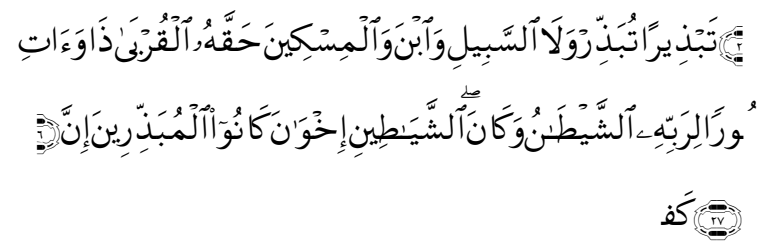

Wa āti żal-qurbā ḥaqqahu wal-miskīna wabnas-sabili wa lā tubażżir tabżìrā. Innalmubażżirinna kānū ikhwānasy-syayāïÊn,wa kÉnasy-syaiīānu lirabbihê kafūrā

Artinya: "dan berikanlah kepada keluarga-keluarga yang dekat akan haknya, kepada orang miskin dan orang yang dalam perjalanan dan janganlah kamu menghambur-hamburkan (hartamu) secara boros. Sesungguhnya pemboros-pemboros itu adalah saudarasaudara syaitan dan syaitan itu adalah sangat ingkar kepada Tuhannya" (Q.S AlIsra'/17:26-27, Departemen Agama Republik Indonesia, 201 1: 284).

Berdasarkan konsep tersebut di atas, bila bank syariah dapat menjalankan kinerjanya secara profesional yang berdasarkan pada prinsip-prinsip syariah yang salah satunya adalah mengelola harta secara benar dan tidak berlebihan, maka bank syariah seharusnya dapat mengelola penghimpunan dana pihak ketiga secara lebih efisien.

\section{Simpulan}

Berdasarkan hasil analisis dan interpretasi data yang dilakukan maka dapat diambil kesimpulan sebagai berikut:

1. Berdasarkan hasil analisis dan interpretasi data, maka dapat disimpulkan bahwa Bank Umum Syariah memiliki tingkat efisiensi penghimpunan dana pihak ketiga dengan asumsi CRS dan VRSyang relatif lebih tinggi namun memiliki tingkat efisiensi penghimpunan dana 
Yuliati, et al/Jurnal Ekonomi Syariah Teori dan Terapan Vol. 3 No. 4 April 2016: 280-294; KOMPARASI EFISIENSI PENGHIMPUNAN DANA PIHAK KETIGA BANK UMUM SYARIAH DAN BANK UMUM KONVENSIONAL DI INDONESIA DENGAN METODE DATA ENVELOPMENT ANALYSIS

pihak ketiga dengan asumsi scale efficiency yang relatif lebih rendah bila dibandingkan dengan Bank Umum Konvensional. Hal ini menunjukkan bahwa sumber inefisiensi atau ketidakefisienan pembiayaan pada Bank Umum Syariah adalah karena skala atau size dana pihak ketiga yang dihimpun.

2. Tidak terdapat perbedaan yang signifikan efisiensi penghimpunan dana pihak ketiga dengan asumsi CRS pada Bank Umum Syariah dan Bank Umum Konvensional yang ditunjukkan dengan nilai signifikansi uji beda Mann-Whitney U-Test sebesar 0,735 lebih dari nilai $\mathrm{a}=0,05\left(\mathrm{H}_{1}\right.$ ditolak)

3. Tidak terdapat perbedaan yang signifikan efisiensi penghimpunan dana pihak ketiga dengan asumsi VRS pada Bank Umum Syariah dan Bank Umum Konvensional yang ditunjukkan dengan nilai signifikansi uji beda Mann-Whitney U-Test sebesar 0,188 lebih dari nilai $\mathrm{a}=0,05 \quad\left(\mathrm{H}_{1}\right.$ ditolak $)$

4. Tidak terdapat perbedaan efisiensi skala dana pihak ketiga yang dihimpun (Scale Efficiency) pada Bank Umum Syariah dan Bank Umum Konvensional yang ditunjukkan dengan nilai signifkansi uji beda MannWhitney U-Test sebesar 0,188 dan juga nilai signifikansi uji beda kolmogorovSmirnov Z-Test sebesar 0,125 lebih dari nilai $\mathrm{a}=0,05\left(\mathrm{H}_{1}\right.$ ditolak)

\section{DAFTAR PUSTAKA}

Ascarya. 2006. Akad \& Produk Bank Syariah.edisi 1. Jakarta: PT. Raja Grafindo Persada

Bastian, Indra dan Suhardjono. 2006. Akuntansi Perbankan. Buku 2. Jakarta: Salemba Empat

Hadad, Muliaman D.,dkk. 2003. Analisis Efisiensi Industri Perbankan Indonesia: Penggunaan Metode Nonparametrik Data Envelopment Analysis (DEA). Buletin Ekonomi dan Perbankan, Vol 1 (7), pp. 1-28

Hamka. 2007. Tafsir Al-Azhar JUZ XV. Jakarta: PTS Publications \& Distributions Sdn, Bhd

Hidayat, Rahmat. 2014. Efisiensi perbankan syariah: teori dan praktik. Bekasi : Gramata publishing

Kamaruddin, Badrul Hisham,et.al. 2008. Assesing Production Efficiency of Islamic Banks and Conventional Bank Islamic Windows in Malaysia. International Journal of Business and Management Science, Vol 1 (1), pp. 31-48

Kumar, Sunil dan Rachita Gulati. 2008. An Examination of Technical, Pure Technical, and Scale Efficiencies in Indian Public Sector Banks Using Data Envelopment Analysis. Eurasian Journal of Business and Economics, Vol. 1 (2), pp.33-69

Otoritas Jasa Keuangan(OJK).2013. Laporan Perkembangan Keuangan Syariah Tahun 2013. (http://www.ojk.go.id/publikasi-laporanperkembangan-keuangan-Syariah- 
Yuliati, et al/Jurnal Ekonomi Syariah Teori dan Terapan Vol. 3 No. 4 April 2016: 280-294; KOMPARASI EFISIENSI PENGHIMPUNAN DANA PIHAK KETIGA BANK UMUM SYARIAH DAN BANK UMUM KONVENSIONAL DI INDONESIA DENGAN METODE DATA ENVELOPMENT ANALYSIS

2013, diakses pada tanggal 25 Oktober 2015) .2014 .

Statistik Perbankan Indonesia Desember 2014. (http://www.ojk.go.id/statistikperbankan-indonesia-desember-2014), diakses pada tanggal 25 Oktober 2015) Pratikto, Heri dan lis Sugianto. 2011. Kineja Efisiensi Bank Syariah Sebelum dan Sesudah Krisis Global Berdasarkan Data Envelopment Analysis. Jurnal Ekonomi Bisnis, Vol.16(2), pp.108-117

Sari, Ditta Feicyllia. 2015. Analisis Efisiensi Pembiayaan Bank Umum Syariah Dan Bank Umum Konvensional Di Indonesia Dengan Metode Data Envelopment Analysis (DEA). Skripsi tidak dipublikasikan. Fakultas Ekonomi dan Bisnis Universitas Airlangga Surabaya Sukirno, Sadono. 2008. Mikro Ekonomi: Teori Pengantar. Jakarta: PT. Raja Grafindo Persada

Sullivan, Arthur and Steven M. Sheffrin. 2003. Economics: Principles in action. Upper Saddle River, New Jersey 07458: Pearson Prentice Hall.

Wahab, Abdul dkk. 2014. Komparasi Efisiensi Teknis Bank Umum Konvensional (BUK) dan Bank Umum Syariah (BUS) Di Indonesia Dengan Metode Data Envelopment Analysis (DEA). Al-lqtishad, Vol. VI No.2, Juli 2014 